\title{
COMUNICACÃ̃
}

\section{Ocorrência de Meloidogyne enterolobii em goiabeira no município de São Manuel, estado de São Paulo}

\author{
Marylia Gabriella Silva $\operatorname{Costa}^{1} \oplus$, Júlio César Antunes Ferreira ${ }^{1} \oplus$, Alixelhe Pacheco Damascena ${ }^{1} \oplus$, \\ Vanessa Rafaela de Carvalho ${ }^{2}$, Sarita Leonel ${ }^{1} \oplus$, Silvia Renata Siciliano Wilcken ${ }^{1} \oplus$
}

${ }^{1}$ Departamento de Proteção Vegetal, Universidade Estadual Paulista (UNESP), Faculdade de Ciências Agronômicas, Av. Universitária, 3780, CEP 18610-034, Botucatu, SP, Brasil. ²Laboratório Central Multiusuário, Universidade Estadual Paulista (UNESP), Faculdade de Ciências Agronômicas, Av.a Universitária, 3780, CEP 18610-034, Botucatu, SP, Brasil.

Autor para correspondência: Marylia Gabriella Silva Costa (marylia_gabriella@hotmail.com)

Data de chegada: 11/06/2020. Aceito para publicação em: 20/08/2020.

$10.1590 / 0100-5405 / 239445$

A goiabeira (Psidium guajava L.), originária da América tropical (3), enfrenta declínio em sua produção desde o surgimento do nematoide Meloidogyne enterolobii. Em amostragem realizada em março de 2018, no município de São Manuel/SP, Brasil $\left(22^{\circ} 75^{\prime} \mathrm{S}, 48^{\circ}{ }^{\prime} \mathrm{W}\right)$, foram observadas galhas nas raízes e bronzeamento arroxeado nas folhas de goiabeira (cultivar Paluma) (figuras $1 \mathrm{~A}$ e $1 \mathrm{~B}$, respectivamente). O material foi levado ao Laboratório de Nematologia Agrícola da Faculdade de Ciências Agronômicas da Universidade Estadual Paulista - Júlio de Mesquita Filho, câmpus Botucatu- SP. As raízes foram processadas para extração dos nematoides de acordo com o método proposto por Coolen \& D'Herde (2). Realizaram-se lâminas baixas para a observação dos juvenis em microscópio de luz e cortes da configuração perineal de fêmeas de Meloidogyne conforme a técnica de Taylor \& Netscher (7). Observou-se a região do padrão perineal com o arco dorsal alto e arredondado e estrias finas. Constatou-se a presença de linha lateral única, que ocorre em um lado do padrão em junção dos arcos dorsal e ventral (figura 1C), esta também foi observada por Rammah \& Hirschmann (6) quando realizaram a descrição original de Meloidogyne mayaguensis, que agora é considerado como sinonímia de $M$. enterolobii. O padrão perineal foi semelhante ao encontrado por Poornima et al. (5) em espécies de M. enterolobii parasitando goiabeira na Índia. Com a finalidade de confirmar a espécie do nematoide foi realizada extração do DNA genômico, de acordo com método adaptado por Carvalho et al. (1). Foram utilizados primers específicos para o gênero Meloidogyne e visualizada banda em transiluminador de luz UV (Major Science). A amplificação utilizando os marcadores Me-F/ Me-R foi positiva para M. enterolobii, gerando fragmento de $256 \mathrm{pb}$ (4) (figura 1D). Posteriormente, o produto de PCR foi submetido à sequenciamento Sanger (ABI 3500, Applied Biosystems). A sequência obtida foi alinhada utilizando o programa Geneious e comparada com banco de dados (GenBank), mostrando semelhança de 97\% com $M$. enterolobii (número de acesso MH800967.1).

\section{REFERÊNCIAS}

1. Carvalho, V.R.; Wilcken, S.R.S.; Wilcken, C.F.; Castro, B.M.C.; Soares, M.A.; Zanuncio, J.C. Technical and economic efficiency of methods for extracting genomic DNA from Meloidogyne javanica. Journal of Microbiological Methods, Netherlands, v.157, p.108-112, 2018.

2. Coolen, W.A.; D'Herde, C.J. A method for quantitative extration of nematodes from plant tissue. Bélgica: State Nematology and Entomology Research Station, 1972.
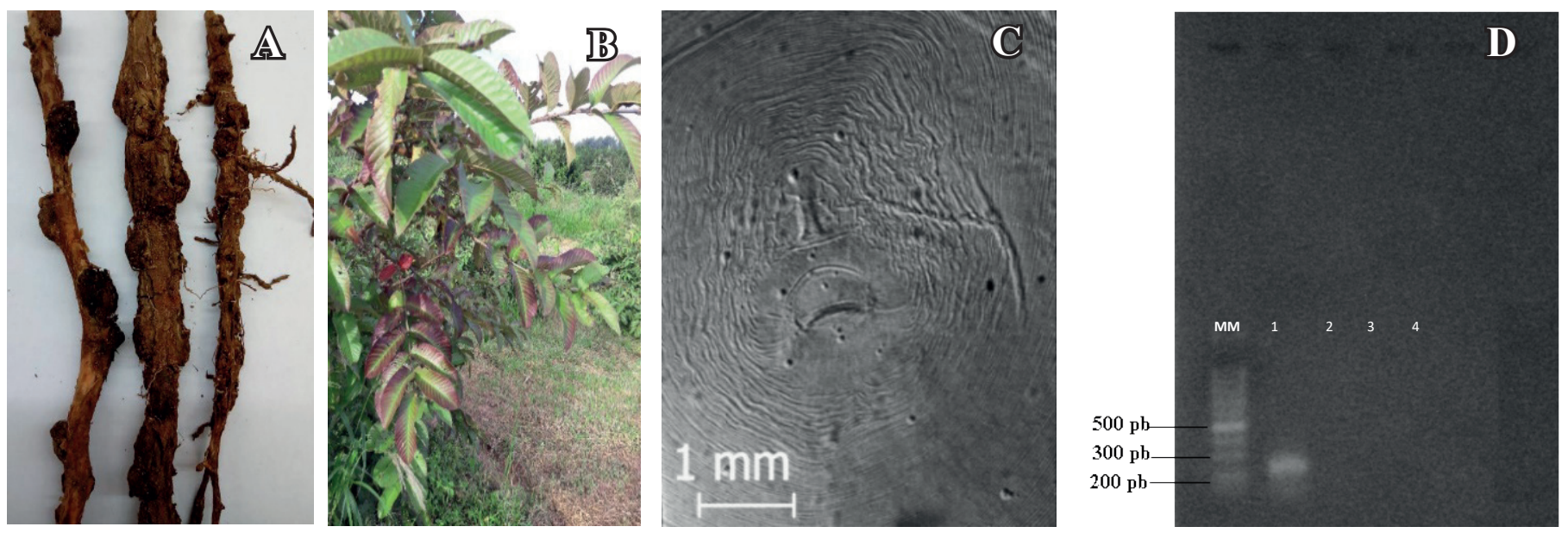

Figura 1. A - Galhas no sistema radicular causadas por M. enterolobii. B - Bronzeamento arroxeado nas folhas. C- Configuração da região perineal de M. enterolobii. D - Gel de agarose 1\%. MM: Marcador molecular 100 pb; 1: Positivo para M. enterolobii; 2: Negativo para Meloidogyne incognita; 3: Negativo para Meloidogyne javanica; 4: Negativo para Meloidogyne exigua; controle negativo utilizando água nuclease free. 
3. Lazan, H.; Ali, Z.M. Guava. In: Shaw, P.E.; Chan Jr., H.T.; Nagy, S. (ed.). Tropical and Subtropical Fruits. Auburndale: AgScience, 1998, p.446485.

4. Long, H.; Liu, H.; Xu, J.H. Development of a PCR diagnostic for the rootknot nematode Meloidogyne enterolobii. Acta Phytopathologica Sinica, China, v.36, n.2, p.109-115, 2006.

5. Poornima, K.; Suresh, P.; Kalaiarasan, P.; Subramanian, S.; Ramaraju, K. Root Knot Nematode, Meloidogyne enterolobii in Guava (Psidium guajava
L.) A New Record from India. Madras Agricultural Journal, Coimbatore, v.103, p.359-365, 2016.

6. Rammah, A.; Hirschmann, H. Meloidogyne mayaguensis n.sp. (Meloidogynidae), a root knot nematode from Puerto Rico. Journal of Nematology, Lawrence, v.20, n.1, p.58-69, 1988.

7. Taylor, D.P.; Netscher, C. An improved technique for preparing perineal patterns of Meloidogyne spp. Nematologica, Wagheningen, v.20, p.268269, 1974. 